\title{
PELATIHAN PTK (PENELITIAN TINDAKAN KELAS) BAGI GURU SMA NEGERI 2 PLUS SIPIROK
}

\author{
Elisa $^{1)}$; Ainun Mardiyah ${ }^{2)}$; Nova Irwan ${ }^{3)}$ \\ ${ }^{1,2,3)}$ Pendidikan Fisika, FKIP Universitas Muhammadiyah Tapanuli Selatan \\ elisahanif@gmail.com
}

\begin{abstract}
Dedication activities are motivated by the importance of conducting classroom action research in making changes in improving the quality of education. The purpose of community service is to increase the interest of writing PTK for teachers and students create and innovative teachers have as an educator so that educator goals can be achieved. The formulation of the problem in this devotion is (1) How the teacher's fundamental knowledge about PTK. (2) How creativity and activity of teacher in writing. This religious activity is held for three meetings. The first meeting discusses fundamental knowledge of PTK by providing an initial skill test. The second meeting discusses the preparation of PTK proposals and the implementation of PTK. While at the third meeting discussed the processing of data results and preparation of the final report. Based on observations during community service activities, some positive results were obtained: (1) Participants showed very high attention to community service materials. (2) The participants actively asked in exposing the problems faced during this time when making PTK. (3) From the initial test consists of 20 questions about knowledge of PTK. From the initial data obtained, only two people or about $13.33 \%$ of teachers who can answer and get a score above the KKM, while 13 people or about $86.7 \%$ of teachers have not been able to answer and earn, score below KKM. After the final test is obtained, almost all teachers around $98.97 \%$ of teachers can answer and score above KKM. The result of community service is increasing the insight of high school teacher N 2 Plus Sipirok on the preparation of PTK (classroom action research).
\end{abstract}

Keywords: Classroom action Research, teacher, proposal.

\begin{abstract}
Abstrak
Kegiatan pengabdian dilatarbelakangi pentingnya pelaksanaan penelitian tindakan kelas dalam melakukan perubahan dalam peningkatan kualitas pendidikan. Tujuan pengabdian masyarakat ini untuk meningkatkan minat menulis PTK bagi guru dan sisis kreativitas dan inovatif yang dimiliki guru sebagai pendidik sehingga tujuan pendidik dapat tercapai. Rumusan masalah dalam pengabdian ini adalah: (1) Bagaimana pengetahuan awal guru mengenai PTK. (2) Bagaimana kreativitas dan aktivitas guru dalam menulis. Kegiatan pengabdian ini dilaksanakan selama 3 kali pertemuan. Pertemuan pertama membahas mengenai pengetahuan awal PTK dengan cara memberikan tes kemampuan awal. Pertemuan kedua membahas mengenai penyusunan proposal PTK dan pelaksanaan PTK. Sedangkan pada pertemuan ketiga membahas mengenai pengolahan data hasil dan penyusunan laporan akhir. Berdasarkan pengamatan selama kegiatan pengabdian masyarakat, diperoleh beberapa hasil yang positif di antaranya adalah: (1) Para peserta menunjukkan perhatian yang sangat tinggi terhadap materi pengabdian masyarakat. (2) Para peserta aktif bertanya dalam mengungkapkan masalah-masalah yang
\end{abstract}


dihadapi selama ini ketika membuat PTK. (3) Dari Tes awal terdiri atas 20 soal mengenai pengetahuan PTK. Dari data awal yang diperoleh, hanya 2 orang atau sekitar 13,33\% guru yang mampu menjawab dan memperoleh skor diatas KKM, sedangkan 13 orang atau sekitar 86,7\% guru belum mampu menjawab dan memperoleh, skor dibawah KKM. Setelah dilakukan tes akhir yang diperoleh, hampir seluruh guru sekitar 98,97\% guru mampu menjawab dan memperoleh skor diatas KKM.Hasil dari pengabdian masyarakat adalah bertambahnya wawasan guru SMA N 2 Plus Sipirok mengenai penyusunan PTK (Penelitian tindakan kelas).

Kata Kunci : Penelitian Tindakan Kelas (PTK),Guru, Proposal

\section{PENDAHULUAN}

Daerah Sipirok sebagai ibukota dari kabupaten Tapanuli Selatan, memegang peranan penting dalam hal pendidikan. Oleh karena itu tidak berlebihan jika pemerintah daerah memberikan perhatian yang serius dalam peningkatan pendidikan. Peningkatan pendidikan dapat tercapai tidak terlepas dari kualitas pendidiknya, sehingga banyak kegiatan yang dilakukan agar kualitas pendidik dapat meningkat. SMA N 2 Plus Sipirok sebagai Pilot Project kualitas pendidikan di sipirok khususnya dan tapanuli selatan pada umumnya, tentu memegang peranan yang sangat sentral sekali. Guru-guru yang berada di SMA 2 Plus Sipirok, diharapkan dapat menjadi role model bagi guru-guru lainnya se-tabagsel.

Penelitian Tindakan Kelas (PTK) dipandang sebagai bentuk penelitian peningkatan kualitas pembelajaran yang paling tepat karena selain sebagai peneliti guru juga bertindak sebagai pelaksana PBM sehingga tahu betul permasalahan yang dihadapi, dan kondisi yang ingin dicapai. Namun antusiasme guru masih kurang karena keterbatasan kemampuan dan pengalaman penelitian, sehinggaserapan dana kurang optimal. Disamping itu karena keterbatasan pengetahuan dan pengalaman penelitian, hasil-hasil pelaksanaan PTK yang terlaksana masih kurang mencerminkan PTK, kebanyakan hasil penelitian tindakannya masih rancu dengan penelitian dengan analisis statistik.

Disisi lain dengan adanya pengabdian masyarakat yang berkaitan dengan penelitian tindakan akan diperoleh beberapa manfaat antara lain : dalam PLPG (Pendidikan Latihan Profesi Guru) guru untuk mengikuti uji sertifikasi juga diberi materi PTK, bagi guru yang PNS dapat mendongkrak angka kredit dalam pengurusan kenaikan pangkat. Menurut Elliot dalam Rochiati Wiriatmaja (2005) penelitian tindakan kelas bukan hanya bertujuan untuk menghasilkan pengetahuan atau teori, melainkan menghasilkan produk berupa peningkatan kemampuan intelektual siswa.

Berdasarkan hasil wawancara dengan beberapa guru yang mengajar di SMA 2 Plus Sipirok, terdapat beberapa kendala yaitu kurangnya pengetahuan guru tentang pembuatan PTK, jauhnya lokasi sekolah sehingga tidak memungkinkan dalam memperoleh informasi dan belum adanya sosialisasi dan pelatihan mengenai PTK. Selain wawancara dengan guru, peneliti juga melakukan wawancara dengan kepala sekolah dan didapatlah beberapa kesimpulan bahwa diharapkan pelatihan PTK yang akan diadakan dapat mewabahkan budaya menulis bagi guruguru dan juga dapat meningkatkan daya kreativitas dan inovatif guru dalam pembelajaran, hal ini dikarenakan fokus PTK bukanlah pada silabus atau materi tetapi pada kelas dan proses belajar mengajar. Terdapat beberapamanfaat PTK bagi guru antara lain; membuat guru peka 
Elisa, dkk. Pelatihan PTK (Penelitian Tindakan Kelas)...

dan tanggap terhadap dinamika atau permasalahan pembelajaran dikelas, meningkatkan kinerja guru, Guru mampu memperbaiki proses pembelajaran melalui suatu kajian yang dalam terhadap apa yang terjadi dikelas, PTK tidak mengganggu tugas pokok guru dan guru menjadi lebih kreatif dan inovatif.

Menurut Fx Soedarsono (2001) terdapat beberapa karakteristik PTK diantaralain; didasarkan pada masalah yang dihadapi guru dalam pembelajaran, kolaborasi dalam pelaksanaannya, peneliti sekaligus sebagai praktisi yang melakukan refleksi, bertujuan memperbaiki atau meningkatkan kualitas pembelajaran dan dilaksanakan dalam rangkaian langkah dengan beberapa siklus. Selain itu terdapat pula beberapa langkah-langkah dalam pelaksanaan PTK, yaitu identifikasi dan analisis masalah, merumuskan masalah, merumuskan hipotesis tindakan, pembuatan rencana tindakan, melaksanakan tindakan dan mengamatinya, mengolah dan menafsirkan data, validasi data dan kredibilitas PTK dan melaporkan hasil penelitian.

Dari hasil wawancara tersebut, maka tidaklah dianggap berlebihan jika Pelatihan PTK dianggap hal yang sangat perlu diadakan di SMA 2 Plus Sipirok.Pelatihan tersebut dianggap sebagai pionir dalam meningkatkan minat menulis bagi guru dan sisi kreativitas dan inovatif yang dimiliki guru sebagai pendidik sehingga tujuan pendidikan dapat tercapai.

\section{METODE PELAKSANAAN}

Untuk mewujudkan hasil yang diharapkan beberapa kegiatan yang telah dilakukan adalah :

(1) Mengadakan konsultasi dan meminta ijin kepada kepala sekolah SMA Negeri 2 Plus Sipirok mengenai pelaksanaan kegiatan pengabdian.
(2) Melakukan koordinasi dengan PKS mengenai tempat, waktu serta jumlah peserta dan susunan acara pelatihan.

(3) Mempersiapkan materi pelatihan diantaranya pembuatan modul serta soal pre tes. Setelah persiapan selesai, ditetapkan waktu kegiatan yaitu pada tanggal 12 april 2017 pada pukul 09.00 - 16.00 wib di SMA N 2 Plus Sipirok.

Metode pelaksanaan program yang dilakukan adalah:

(1) Penyuluhan mengenai PTK,

(2) Pelatihan Penulisan PTK bagi guruguru,

(3) Pengolahan data untuk PTK.

Kegiatan yang telah dilakukan oleh tim pengabdian adalah :

(1) Penyampaian materi tentang PTK,

(2) Sharing dengan guru-guru mengenai kesulitan yang dialami selama ini ketika menulis PTK,

(3) Penyampaian materi mengenai teknik pengolahan data pada PTK

\section{HASIL DAN PEMBAHASAN}

Kegiatan program IbM Pelatihan PTK (Penelitian Tindakan Kelas) Bagi guru SMA Negeri 2 Plus Sipirok di Desa Padang Bujur Kecamatan Sipirok dilaksanakan berdasarkan atas perencanaan yang telah dibuat. Sampai saat ini kegiatan yang sudah dilakukan adalah sebagai berikut :

(1) Pengenalan PTK(Penelitian Tindakan Kelas) Kegiatan ini dilaksanakan di SMA N 2 Plus Sipirok yang bertempat di Desa Padang Bujur Kecamatan Sipirok Kabupaten Tapanuli Selatan. Kegiatan ini dihadiri oleh sekitar 20 orang guru. 


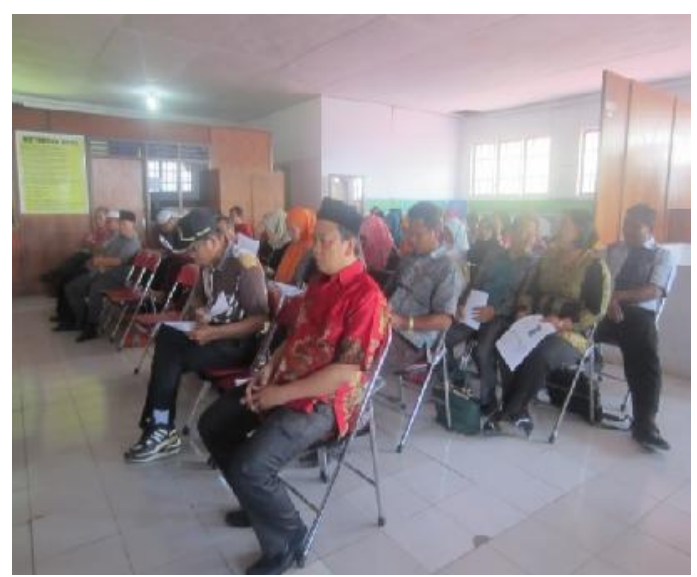

Gambar 1: Workshop hari pertama

Dalam kegiatan ini, mitra diminta untuk menjawab soal tentang pengetahuan awal tentang PTK. Selain itu juga membahas tentang perihal kegiatan yang akan dilakukan pada pertemuan selanjutnya, sehingga kelompok PTK mampu mempersiapkan diri dalam mengikuti workshop.

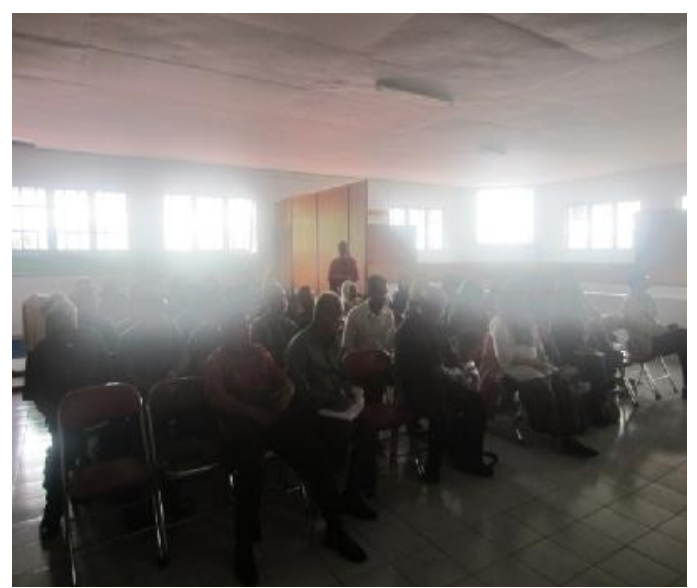

Gambar 2: Pengenalan PTK (Penelitian Tindakan Kelas)

(2) Workshop II, Kegiatan ini dilaksanakan di SMA N 2 Plus Sipirok, tetapi tidak seluruh guru yang hadir pada pertemuan awal dapat hadir, dikarenakan akan diadakannya UN di sekolah tersebut. Sehingga hanya guru honorer saja yang dapat hadir. Kegiatan workshop dilaksanakan di ruang kelas. Di dalam kegiatan ini diberikan mengenai PTK dan bagaimana cara menulis PTK.

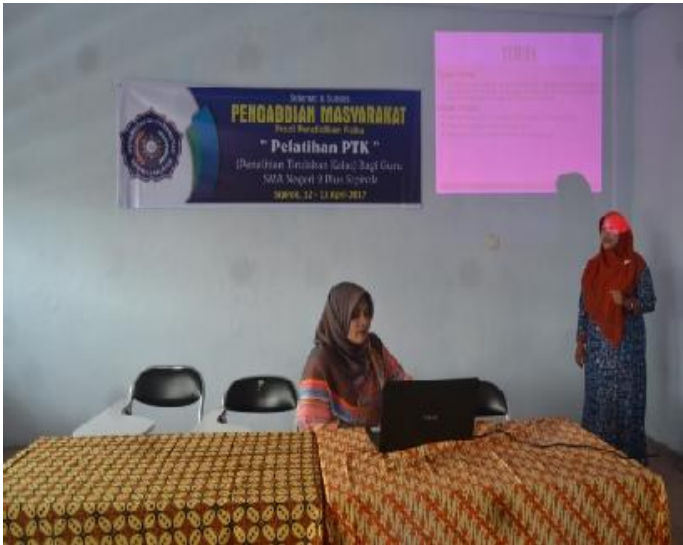

Gambar 3: Workshop hari kedua

(3) Workshop PTK III, Pada kegiatan ini dibentuk beberapa kelompok dalam pengolahan data untuk PTK.

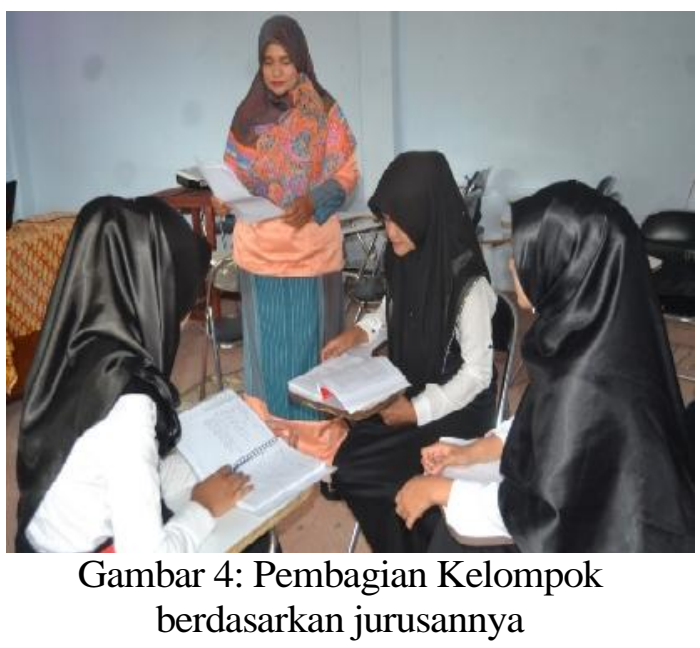

\section{SIMPULAN}

Pada penelitian pendahuluan dilakukan tes awal untuk mengetahui pemahaman awal guru mengenai PTK (Penelitian Tindakan Kelas). Tes awal terdiri atas 20 soal mengenai pengetahuan PTK. Dari data awal yang diperoleh, hanya 2 orang atau sekitar 13,33\% guru yang mampu menjawab dan memperoleh skor diatas KKM, sedangkan 13 orang atau sekitar $86,7 \%$ guru belum mampu menjawab dan memperoleh, skor dibawah KKM. Setelah dilakukan tes akhir yang diperoleh, hampir seluruh guru sekitar 98,97\% guru mampu menjawab dan memperoleh skor di atas KKM. 
Elisa, dkk. Pelatihan PTK (Penelitian Tindakan Kelas)...

\section{UCAPAN TERIMA KASIH}

Penelitian ini terlaksana dengan bantuan berbagai pihak, terimakasih kepada pihak yang sudah membantu. Sumber dana LPPM UMTS kontrak No.Kept 011/KEP/11.3-AU/F/2017 antara Elisa dan Kepala LPPM Universitas Muhammadiyah Tapanuli Selatan.

\section{DAFTAR PUSTAKA}

Fx. Soedarsono. 2001. Aplikasi Penelitian Tindakan Kelas. Direktorat Jenderal Pendidikan Tinggi Departemen Pendidikan Nasional, Jakarta.

Rochiati Wiriatmaja. 2005. Metode penelitian tindakan kelas. Bandung. Rosdakarya. 